\title{
CURRENT INDUCED SEISMICITY IN THE PASKOV MINE FIELD (OSTRAVA REGION)
}

\author{
Karel HOLUB ${ }^{1) *}$, Jana RUŠAJOVÁ ${ }^{1)}$ and Josef HOLEČKO ${ }^{2)}$ \\ 1) Institute of Geonics AS CR, Studentská 1768, CZ 70800 Ostrava-Poruba, Czech Republic \\ 2) Green Gas DPB, a.s., Rudé armády 637, Paskov 739 21, Czech Republic \\ *Corresponding author's e-mail: holub@ugn.cas.cz
}

(Received July 2012, accepted October 2012)

\begin{abstract}
The aim of this paper is to present the results of an investigation of induced seismic events which occurred during mining in the coalfields of Plants Paskov and Staříč of the Paskov Mine which belong to the southern part of the Ostrava-Karviná coal mines. Some results obtained in the time period January 1992 - December 2002 have already been published, and therefore, are mentioned here only briefly. The paper is based on new results of seismological observations at the OKC, KLOK, STEB seismic stations operated by the Institute of Geonics AS CR and stations of the Green Gas DPB, a.s., Paskov. A total of 26 seismic events were monitored from January 2008 to February 2012, most of them were localized into the area under study. As for the energy span of individual events according to the energetic classification of the Geophysical Centre of the Green Gas DPB, a.s., Paskov, all seismic events in Table 1 were estimated within the limits $\mathrm{E}(\mathrm{J})<5.0 \times 10^{2} \div 2.0 \times 10^{4}>$.
\end{abstract}

KEYWORDS: Ostrava-Karviná coal mines, seismic network, induced seismicity, location plot

\section{INTRODUCTION}

Apart from the eastern part of the OstravaKarviná coal mines, its southern part is of considerable interest. These two mentioned parts are incommensurable, particularly with regard to the thickness of their coal seams and level of induced seismic activity. Whereas the thickness of the coal seams in the Karviná mines reaches almost 6-7 m, in the southern part (the Paskov and Staříc Plants) the thickness is roughly $1.5 \mathrm{~m}$, both coalfields are displayed in Fig. 1. It is indeed the extent of winning in the past and present, and the complicated geological and tectonic structure of both parts, in which mining causes instabilities within the rock massif and their gradual, but sometimes even sudden, compensation or redistribution of residual stresses that generates increased seismic activity. This is opposed to the Karviná Basin, where rockbursts and shock phenomena in general represent considerable danger for mine workers and which sometimes cause partial or complete devastation of mine workings. In contrast to this, the southern part of the district the mine workings are endangered by phenomena such as outbursts of coal and gas and by spontaneous rock falls or rock falls after blasting in the roof. These outbursts have occurred from time to time in the past and they also occur in the present. Their occurrence is frequency lower, but the consequences in mine workings, as compared to rockbursts in the Karviná area, are substantially less devastating.

The problem of induced seismic activity in the Ostrava-Karviná coal mines, with particular regard to its southern part, has been the subject of papers published earlier, e.g., Holub et al. (2002), Holub and Rušajová (2004), Holub et al. (2004). This paper essentially ties in with the referenced papers and, in particular, summarizes new results of the research into induced seismic activity in the southern part of the coal deposit in the period from 2008 to February 2012 .

\section{MONITORING NETWORKS}

For the purposes of detection and localization of induced seismic events in the Ostrava-Karviná coal mines, a seismic polygon of 15 stations (Klíma et al., 1984) was originally planned in the middle of the 1980 's and, in the course of being established, was reduced to 10 stations equipped with digital instruments in the Karviná part of the coal deposit. Preliminary results of monitoring based on the operation of five three-component seismic station in this area were described, e.g., by Konečný (1989). To satisfy the original intention of comprehensive monitoring of induced seismic activity also in the southern part of the deposit, it was decided that the Mining Institute AS CR (now the Institute of Geonics AS CR) in Ostrava-Poruba was to be entrusted with the development and manufacture of the equipment for the 5-station network in the Frenštát area. The new system was designed with parameters similar to that of the 10-station system with data radio transmission using the retranslation path via Lysá hora to the Geophysical laboratory of the Mining Institute AS $\mathrm{CR}$, i.e. functioning as an independent seismic network. A brief description of the new equipment, including the $\mathrm{SW}$, is given in the papers of Toth 


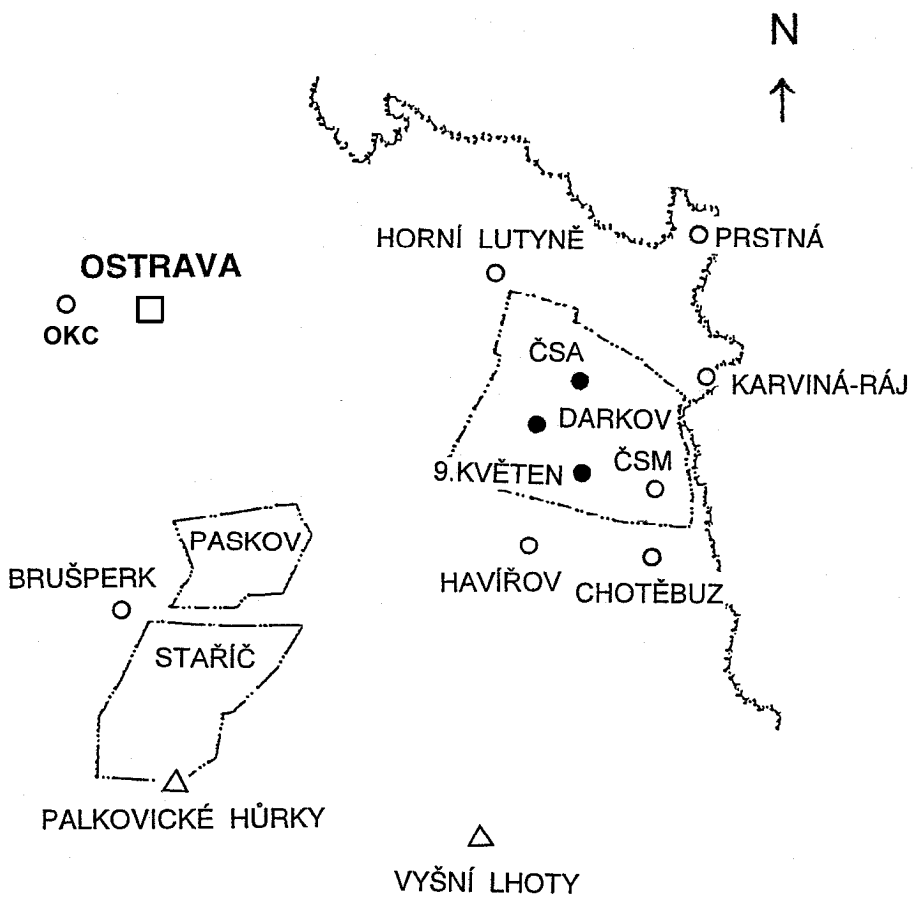

FRENŠTÁT p. Radh. $\triangle$
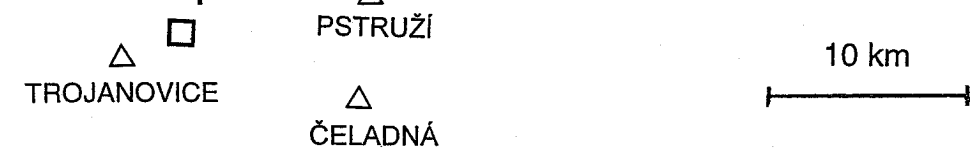

Fig. 1 Planary distribution of both seismic networks: surface $(\circ)$ and underground (•) seismic stations of the former polygon DPB Paskov, $(\triangle)$ surface seismic stations of the Frenštát network.

(1991) and Knejzík and Zamazal (1992). However, as it turned out, in the course of operating the Frenštát Seismic Polygon (SPF) the stations of this network recorded, e.g., natural microearthquakes, quarry blasts carried out in neighbouring quarries, as well as frequent seismic phenomena, including rockbursts, which occurred in the mines of the eastern part of the Ostrava-Karviná coal mines, but also in the coal and ore mines in neighbouring Poland.

The Frenštát seismic network denoted sometimes as SPF, has contributed significantly to the study of induced seismic activity in coalfield of the Paskov Mine. While the mining in the Staříc Plant has been in progress till now, mining in Paskov Plant was closed in June 1999. These stations detected 98 events during the first period of seismological observations (1992-2002) which were successfully localized either by SPF ( 86 events) or by DPB Paskov regional seismological network (43 events) mentioned by Holub et al. (2012). Considering that all seismic stations were equipped with three-component sensors WDS-202 $\left(\mathrm{f}_{0}=2 \mathrm{~Hz}\right)$ so almost 1,300 recording tracks were at our disposal. An example of the complete series of waveforms of seismic event recorded on January 13, 1993 is given in Figure 2.
Later the increasing activity in this area caused us to move the equipment of the surface station in the area of the ČSM mine to the Brušperk locality (see Fig. 1), which is substantially closer to the focal regions in the Paskov and Staříč mine fields, in order to improve detection and thus also the accuracy of localization. It should be stressed there that the SPF network was operated without failure from December 1998 to December 2002. The assessment of its contribution to the monitoring of induced events in the Frenštát area has been described in the summarizing paper by Holub et al., (2004). After the operation of the SPF was terminated, the quality of the information on the activity in both the mine fields deteriorated. During the period January 2003 - December 2007 the observation of the appropriate seismic events from Frenštát area were stopped and restarted from January 2008.

\section{PRESENT CONDITION OF MONITORING INDUCED EVENTS IN THE PASKOV - STAŘíČ AREA}

After the operation of the local SPF seismic network was terminated, only the Brušperk station remained in the original well monitored area, because 


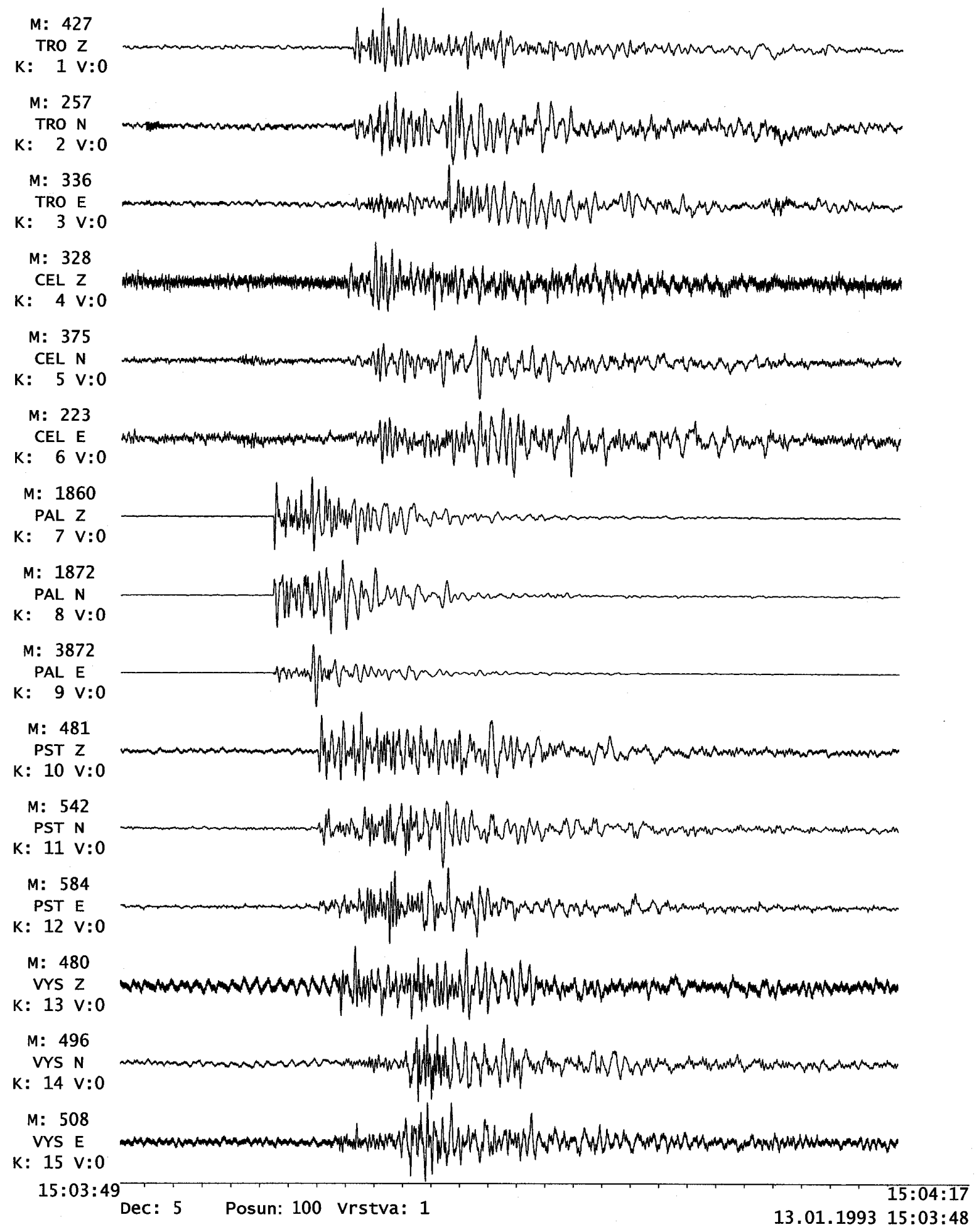

Fig. 2 The complete waveforms of the seismic induced event in the Paskov Mine, Plant Staříc on January 13, 1993 recorded by the SPF network.

most seismic stations of the regional network operated by Green Gas DPB, a.s., Paskov, whose data can be used for localization, are located in the eastern part of the Ostrava-Karviná coal mines. In order to record at least the stronger events from Paskov and Staříč Plants, station Brušperk has now a larger weight for triggering events. The stronger of these, which are localized, are then stored in the database of seismic events and annotated "Staříčc". A number of weaker events are also detected but, because they cannot be localized, their records are labelled as noise, which is later erased.

The essential intention of this renewed analysis was to clarify the occasional occurrence and character 


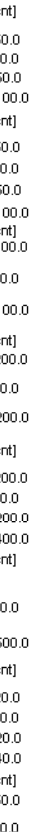

KLOK (Z)

2011.04.19(10990259:56.333

KLOK (N)

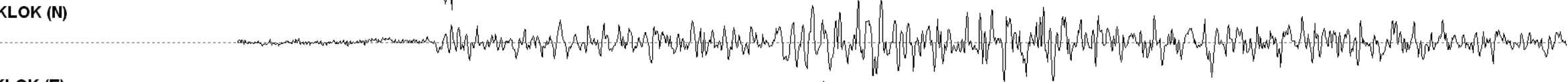

KLOK (E)

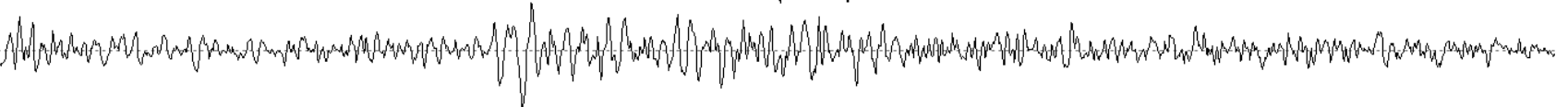

OKC (N)

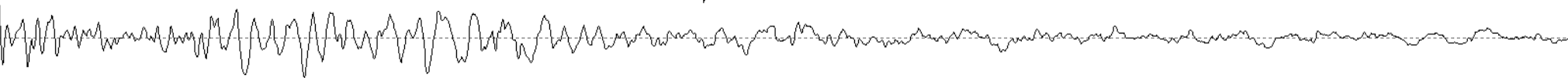

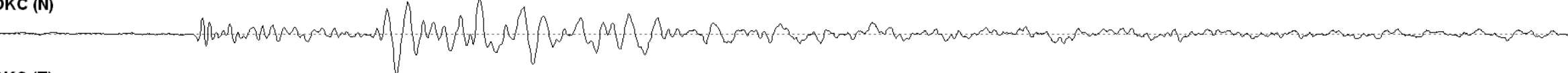

OKC (E)

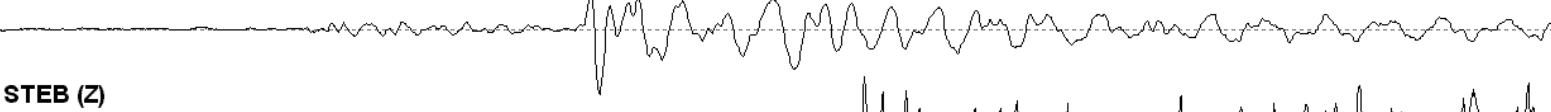

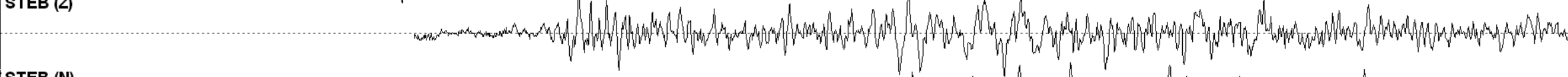

STEB (N)

STEB (E)

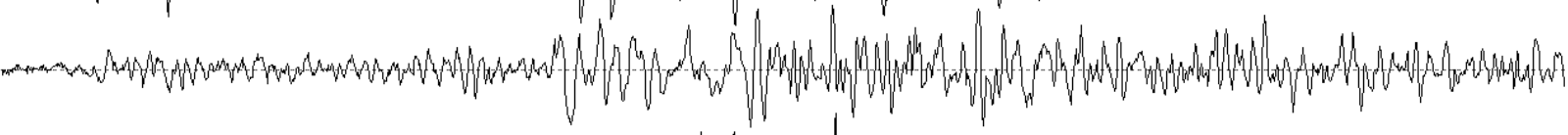

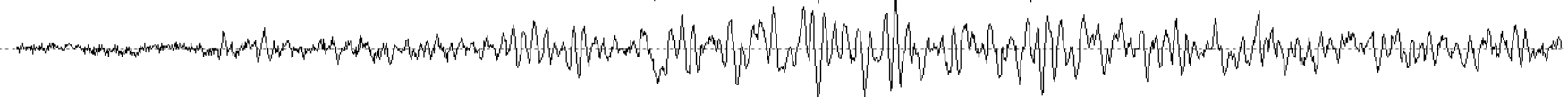

Fig. 3 Seismograms of induced seismic event from April 19, 2011, $\mathrm{H}=02: 59 \mathrm{UTC}$ recorded at the OKC seismic station with short-period seismograph $\mathrm{T}_{0} \approx 1.6 \mathrm{~s}$, sampling frequency $\mathrm{f}=100 \mathrm{~Hz}$, while KLOK and STEB seismic stations are equipped with a short-period instrumentation. $\mathrm{T}_{0}=1.0 \mathrm{~s}$, sampling frequency $\mathrm{f}=100 \mathrm{~Hz}$. 
Table 1 Overview of all 26 detected and localized foci occurring in the broad area of the Paskov and Staříč coal fields.

\begin{tabular}{|c|c|c|c|c|c|c|}
\hline No. & Date & Time (UTC) & $\phi$ & $\lambda$ & $\begin{array}{l}\text { Green Gas - } \\
\text { DPB, Paskov }\end{array}$ & Remark \\
\hline 1 & 4.9.2008 & 21:39:44.694 & $49.7066^{\circ}$ & $18.1931^{\circ}$ & & \\
\hline 2 & 5.9 .2008 & $21: 20: 26.970$ & $49.7349^{\circ}$ & $18.1181^{\circ}$ & & \\
\hline 3 & 9.9 .2008 & $07: 20: 49.703$ & $49.7257^{\circ}$ & $18.2989^{\circ}$ & & \\
\hline 4 & 24.9.2008 & $15: 05: 35.383$ & & & & $\mathrm{KLOK}, \mathrm{OKC}$ \\
\hline 5 & 25.9.2008 & $14: 40: 50.059$ & & & & $\mathrm{OKC}$ \\
\hline 6 & 9.10 .2008 & $11: 19: 31.070$ & & & & KLOK \\
\hline 7 & 11.10 .2008 & $14: 34: 54.445$ & & & & \\
\hline 8 & 25.11 .2008 & $13: 54: 52.932$ & $49.7251^{\circ}$ & $18.3445^{\circ}$ & & \\
\hline 9 & 5.12 .2008 & 04:01:59.741 & $49.6646^{\circ}$ & $18.3591^{\circ}$ & & \\
\hline 10 & 7.12:2008 & $01: 55: 38.146$ & $49.7408^{\circ}$ & $18.2968^{\circ}$ & & \\
\hline 11 & 3.5 .2009 & $17: 10: 04.010$ & $49.7172^{\circ}$ & $18.3683^{\circ}$ & no & \\
\hline 12 & 2.9.2009 & 04:21:53.927 & & & & \\
\hline 13 & 8.10 .2009 & $23: 22: 47.436$ & $49.7196^{\circ}$ & $18.2145^{\circ}$ & & \\
\hline 14 & 11.10 .2009 & $02: 05: 22.717$ & $49.7013^{\circ}$ & $18.2605^{\circ}$ & no & \\
\hline 15 & 18.10 .2009 & $19: 47: 58.840$ & $49.6895^{\circ}$ & $18.3316^{\circ}$ & no & \\
\hline 16 & 22.10 .2009 & $22: 21: 25.295$ & $49.7018^{\circ}$ & $18.3082^{\circ}$ & no & \\
\hline 17 & 30.10 .2010 & $15: 36: 18 . .546$ & $49.6976^{\circ}$ & $18.2813^{\circ}$ & no & \\
\hline 18 & 30.11 .2010 & $23: 47: 20.162$ & $49.6939^{\circ}$ & $18.2618^{\circ}$ & no & \\
\hline 19 & 11.1 .2011 & $23: 21: 07.104$ & $49.6805^{\circ}$ & $18.3024^{\circ}$ & & \\
\hline 20 & 30.3 .2011 & 02:18:48.862 & $49.7277^{\circ}$ & $18.2616^{\circ}$ & & \\
\hline 21 & 19.4.2011 & $02: 59: 55.430$ & $49.6981^{\circ}$ & $18.2981^{\circ}$ & & \\
\hline 22 & 20.8.2011 & $11: 59: 11.384$ & $49.6387^{\circ}$ & $18: 3217^{\circ}$ & & \\
\hline 23 & 11.12 .2011 & $18: 50: 37.730$ & $49.6651^{\circ}$ & $18.2094^{\circ}$ & no & \\
\hline 24 & 11. 2.2012 & 09:07:40.341 & $49.6866^{\circ}$ & $18.2829^{\circ}$ & no & \\
\hline 25 & 14.2.2012 & 01:00:05.366 & $49.7192^{\circ}$ & $18.2280^{\circ}$ & no & \\
\hline 26 & 16.2.2012 & 03:33:09.173 & & & & \\
\hline
\end{tabular}

of induced seismic events on records of the OstravaKrásné Pole $(\mathrm{OKC})$, Klokočov (KLOK) and Stěbořice (STEB) seismic stations of the Institute of Geonics AS CR (hereafter IGN AS CR). While the OKC seismic station is part of the Czech National Seismic Network (hereafter CNSN), the last-named seismic stations, i.e. KLOK and STEB are considered as temporary seismic stations. As regards details related to the stations we refer to http://www.ugn.cas.cz/?1=en\&a=\&p=depart/depart44/soactivity.php. Characteristic seismograms recorded at these three seismic stations are displayed in Figre 3.

It was startling when seismic stations of the IGN AS CR and some stations of the CNSN detected and also localized seismic events which were not detected at seismic stations of Green Gas DPB, a.s., Paskov. That was the reason why we decided to investigate these events and peculiaritis of their occurrence, because seismic stations of all monitoring systems recorded the same event at the same time. At other times the appropriate event was recorded only by one system. Several times it was found that seismic events of unknown nature were recorded only at the stations of the IGN AS CR. However, sometimes no related event among the records of Green Gas DPB, a.s.,
Paskov, was found during a fleeting inspection. Only after detailed analysis of these records it confirmed that some of these weak events were also recorded, but at first glance they were hidden by seismic noise. The next step of general data analysis was to test effects of blasting operations using charges of explosives (max. $400 \mathrm{~kg}$ ). These blasts were applied to disintegrate the rock in the roof above the coal seam, but none of these blasts was recorded. It was concluded, therefore, that these explosions generate seismic waves so weak that they could not be detected at all.

This experience was later reflected in the course of the interpretation and localization of events recorded at the local stations run by the IGN AS, the Institute of the Physics of the Earth (IPE) of the Masaryk University in Brno, and the stations of the nationwide network of the Institute of Geophysics AS CR (IG AS CR) in Prague. An overview of detected induced events is displayed in Table 1, which also proved that induced seismic events from the region of interest have also been recorded to date. After comparison with the data of Green Gas DPB, a.s., Paskov, it was documented that not all seismic events from the mining were included in the database of events. As shown between Sept. 9, 2008 and 


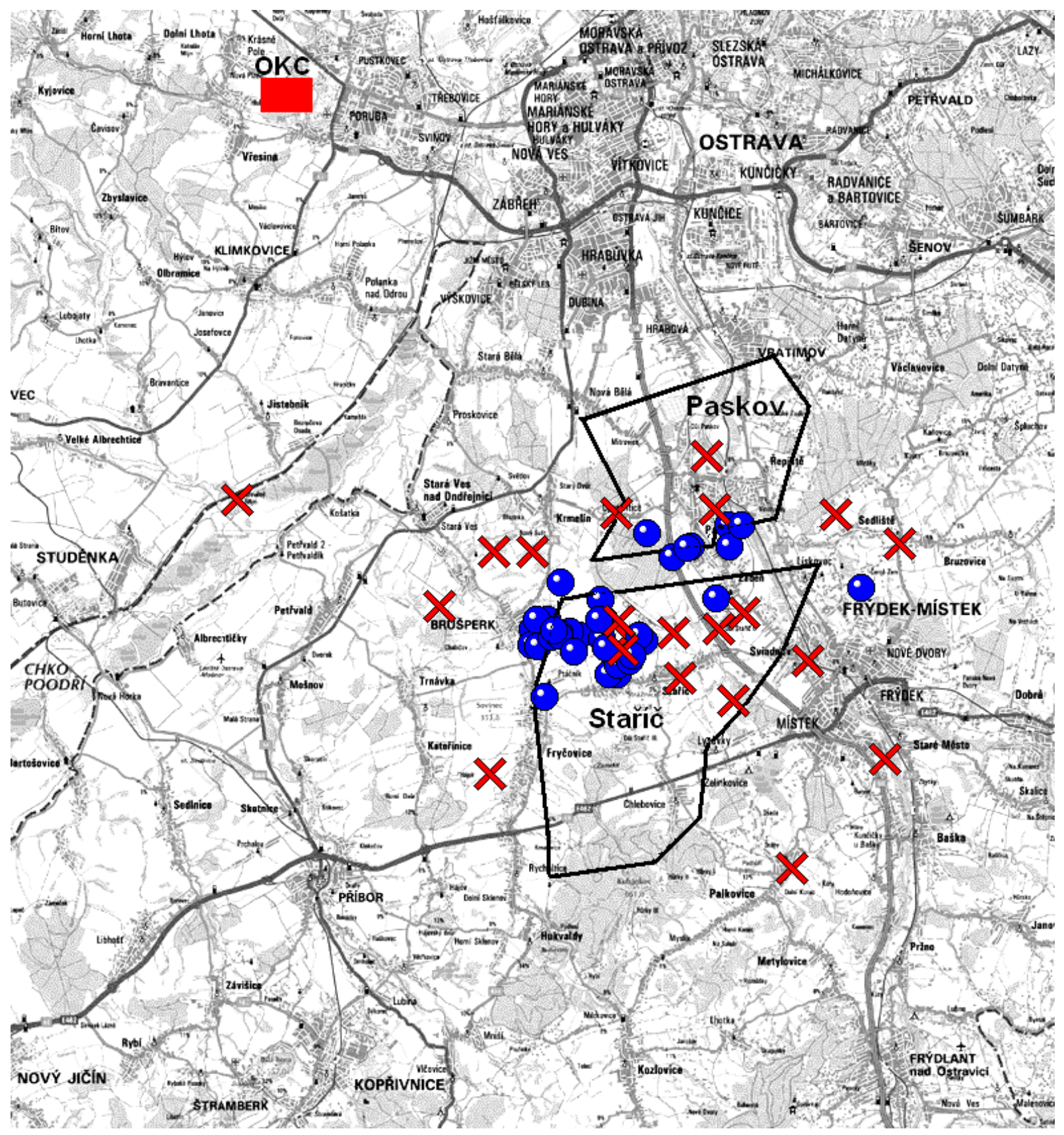

Fig. 4 Detailed view of the OKC seismic station position with a detail of the focal region: $\bullet$ foci determined using data of the original SPF network (acc. to Holub et al., 2004), $\times$ foci calculation based on data of the Institute of Geonics AS CR completed with data from stations of the Czech National Seismological Network.

Feb. 2, 2012 in the area of our interest, 26 events occurred. 21 of them were localized by data of the OKC, KLOK and STEB seismic stations using also data from other seismic stations of the IPE, e.g. Moravský Beroun (MORC) and Vranov u Brna (VRAC) and/or selected nearest seismic stations of the CNSN; relevant geographical coordinates $\varphi_{\mathrm{N}}$ and $\lambda_{\mathrm{E}}$ of the foci are given in Table 1. In three cases, i.e. events Nos $4-6$, where the seismic stations are explicitly cited in the "Remarks" column, means that only these stations detected the appropriate seismic events. On the other hand, regional network of Green
Gas DPB, a.s., Paskov, neither detected, nor localized 9 events which are marked in Table 1 by „no“. Figure 4 displays the position of the OKC seismic station related to calculated foci of individual seismic events. If the scatter of foci is analysed, then it is obvious, that the data relating to the foci determined by the original SPF network (Holub et al., 2004) are less scattered compared with the foci calculated using the input data of IGN AS CR seismic stations OKC, KLOK and STEB complemented with data of the CNSN, e.g. MORC, VRAC. The difference in locations scatter of both monitoring systems results 
from the larger epicentral distances of the seismic stations mentioned last. Only one questionable focus at a distance approx. $12-13 \mathrm{~km}$ to the NW of the centre of the Staříč and Paskov foci cluster is probably not connected with the mining. As regards the comparison of results, the process of data interpretation timing is different. In the Geophysical Centre of the Green Gas DPB, a.s., Paskov, all records are evaluated and interpreted daily, on the other hand, the data from the remote KLOK and STEB seismic stations are available with a delay of one month. This delay considerably complicates the immediate comparison of the localization results of both monitoring systems.

\section{CONCLUSIONS}

In the present paper it was demonstrated that induced seismic events within the area of Paskov and Staříc Plants of the Paskov Mine are detectable, not only by the seismological stations of the Green Gas DPB, a.s., Paskov regional network, but also by seismic stations of the Institute of Geonics AS CR and selected stations of the Czech National Seismological Network (CNSN). Considering that from time to time some induced seismic events have been observed at stations of both systems, then mutual comparison of data interpretation helps to better understand their position, origin and character. When we compare location accuracy using data from the original SPF stations and the present network of the Institute of Geonics AS CR supplied some seismic stations of the CNSN, higher accuracy of location was documented for the system SPF. This is because locations using remote stations are influenced by many factors, i.e., distance between seismic station and seismic source, propagation velocities of seismic waves and their coefficient of attenuation. Moreover, the transfer of the surface station from the Mine ČSM to new site Brušperk at that time was proved and justified by seismic events occurring inside the mining area of the Paskov Mine.

\section{ACKNOWLEDGEMENT}

The data acquisition was supported by the project of large research infrastructure CzechGeo, Grant No. LM2010008. This was performed with the support RVO: 68145535.

\section{REFERENCES}

Holub, K., Rušajová, J. and Holečko, J.: 2002, Occurrence of induced seismic events in Paskov and Staříč Mine Fields. Publs. Inst. Geophys. Pol. Acad. Sc., M-24 (340), 131-141.

Holub, K. and Rušajová, J.: 2004, Induced seismic events in the Staříč and Paskov mine fields, Czech Republic. Acta Montanistica Slovaca, 9, No. 1, 21-27.
Holub, K., Kaláb, Z., Knejzlík, J. and Rušajová, J.: 2004, Frenštát seismic network and its contribution to observations of the natural and induced seismicity on the territory of northern Moravia and Silesia. Acta Geodyn. Geomater., 1 (133), 59-71.

Holub, K., Kaláb, Z., Knejzlík, J. and Rušajová, J.: 2009, Contribution of the Institute of Geonics AS CR Ostrava to seismological monitoring in Silesia and Northern Moravia. Acta Geodyn. Geomater., 6, No. 3 (155), 391-398.

Holub, K., Holečko, J., Rušajová, J. and Dombková, A.: 2012, Long-term development of seismic networks in the Ostrava-Karviná coal mine district. Acta Geodyn. Geomater., 9, No. 2 (166), 115-132.

Kaláb, Z., Knejzlík, J. and Holub, K.: 2007, Decade of seismological observations in the northern part of Moravo-Silesian Region. Acta Geodyn. Geomater., 4, No. 4 (148), 43-49.

Klíma, K., Knejzlík, J., Konečný, P., Pros, Z., Rakowski, Z., Ruprechtová, L., Vaněk, J. and Waniek, L.: 1984, Proposal of Regional Diagnostic Polygon for OstravaKarviná and Frenštát regions. Academy of Sciences of the Czechoslovak Republic, Praha, 59 pp., (in Czech).

Knejzlík, J. and Zamazal, R.: 1992, Local seismic network in southern part of the Ostrava-Karviná Coalfield. Acta Montana, Series A, No. 2 (88), 211-220.

Konečný P.: 1989, Mining-induced Seismicity (Rock bursts) in the Ostrava-Karviná Coal Basin, Czechoslovakia. Gerl. Beitr. Geophysik, 98, No. 6, 525-547.

Toth, R.: 1992, Concept of Programs for Data Analysis from Seismic Polygon Frenštát (SPF). Proc. of Conference of Seismologists, Z. Kaláb (ed.), Inst. of Geonics AS CR, Ostrava, 22-27, (in Czech). 